\title{
Influence of chemical and physical barriers in the intensity of the light curing unit
}

\author{
Diogo de Azevedo Miranda ${ }^{1 *}$, João Pedro Cabreira Oliveira ${ }^{2}$, João Victor Neves de Abreu ${ }^{2}$ and Vitor de Souza Gonçalves ${ }^{2}$ \\ ${ }^{1}$ Adjunct Professor of Faculty of Medical Sciences and Health of Juiz De Fora, Department of Dentistry, Faculty of Medical Sciences and Health of Juiz De Fora, \\ Brazil \\ ${ }^{2}$ Student, Dental of Faculty of Medical Sciences and Health of Juiz De Fora, Department of Dentistry, Faculty of Medical Sciences and Health of Juiz De Fora, \\ Brazil
}

\begin{abstract}
Introduction: Because the light curing agent is a continuous use material that does not allow its sterilization, the dental surgeon should be used for some measures that may reduce the risk of cross infection through its use. Therefore, use asepsis to this physical and / or chemical barriers that may reduce the risk of contamination by the dental surgeon and the patient.

Objective: This study verified the light intensity of light-curing devices and analyzed the influence of physical and / or physical barriers on the final intensity of actions by the devices. Method. 13 photopolymerizers from the Schuster Emitter AFIT brand were used for each of the five groups of readings for each group tested: without barriers, chemical barriers ( $70 \%$ alcohol), physical barriers (70\% sugar, followed by the plastic bag). The intensity of the light will be verified through a calibrated radiometer of the brand ECEL RD-7.
\end{abstract}

Results: After statistical analysis one can verify what was done when a barrier was not used with the groups that used physical barrier and with the group that made association of barriers.

Conclusion: Regarding biosafety, an association of physical and tissue barriers, although they had lower irradiance results, ensure better protection of the devices and avoid cross-contamination without prejudicing the clinical procedures.

\section{Introduction}

The use of composite resins allows more and more strength in dentistry to suit a series of physical, chemical and biological requirements, as well as the ability of such exercise material, function and esthetics to the dental element. Another function of these restorative materials that facilitate the clinical practice of dentists is in relation to their polymerization [1]. Photopolymerized resins have in their composition photoinitiators - as a can for contact with light, they react and form free radicals that initiate the conversion of monomers into polymers $[2,3]$. To the right extent, the polymerization is $400 \mathrm{~mW}$ $/ \mathrm{cm}^{2}$, with a time of $40 \mathrm{~s}(\mathrm{~cm})$, for increments of $2 \mathrm{~mm}$ (millimeters) thick, with a minimum value of $300 \mathrm{~mW} / \mathrm{cm}^{2}$; in this case, an additional polymerization time of $[2,4-6]$ is required.

A subpolymerization will lead to increased microleakage, mmicrohardness reduction, postoperative sensitivity and aesthetic impairment; The polymerization with the light intensity and the high rate of contraction force, the movement of a pink tooth region and energy, the generation of spaces for the propagation of buccal fluids and the communication media [2,6-8].

The photopolymerizer is an important equipment for the success of adhesive / restorative procedures performed by the dental surgeon. Because it is a combination of continuous use and does not allow its sterilization, the dental surgeon should be aware of some measures to reduce or reduce the risk of cross infection through its use. Therefore, physical and / or chemical barriers should be used for the asepsis of this instrument, in addition to other substances aimed at reducing the risk of contamination by the dentist and the patient 9 . The more compact LEDs convert electricity directly into blue light, they do not require cooling mechanisms and the heat generated is lower than those of halogen light, with a useful path between 10.000 and 100.000 hours $[3,8,9]$.

The periodic maintenance of the appliances is extremely important in order to detect any defects that might compromise the light intensity and the quality of the restorations [10]. The apparatus for measuring the irradiance is called a radiometer and these use different measurement scales.

Thus, in addition to the careful selection of the material and the correct restorative technique, the use of photopolymerizers with adequate power contributes significantly to the success of restorations [7]. Considering that one of the main causes of clinical failure of direct aesthetic restorations is the insufficient polymerization of the composite resin, which makes the restoration more susceptible to surface staining, marginal infiltration and the presence of residual monomers [9], it is essential to verify of the photopolymerizer.

${ }^{\star}$ Correspondence to: Diogo de Azevedo Miranda, Rua Sampaio 330/602, Granbery, Juiz de Fora, Minas Gerais 36010-360, Brazil, E-mail: diogoodonto@yahoo.com.br

Key words: dental curing lights, dental infection controls, polymerization

Received: November 03, 2018; Accepted: November 21, 2018; Published: November 26, 2018 
Therefore, this in vitro study verified the light intensity of the photopolymerizing devices used in the dental graduation clinic and analyzed the influence of physical and / or chemical barriers on the final intensity emitted by them, in order to improve performance and reduce the risk of contamination.

\section{Methods}

\section{Experimental design}

The present study was of experimental character, whose sample, was composed of 13 photopolymerizers, in perfect state of use, that were with its loader base connected to a socket. Schuster Emitter A FIT photopolymerizers and physical barriers (plastic bags) and chemical barriers $\left(70^{\circ}\right.$ alcohol) were used, as well as the association of the two barriers.

The apparatus used was left 24 hours coupled to the loader base so that the maximum intensity was guaranteed during the tests. For each apparatus, 5 consecutive readings were performed, according to the groups tested: without any type of barrier, light intensity after physical barrier (plastic bag) placement, light intensity after the use of chemical barrier $\left(70^{\circ}\right.$ alcohol) and intensity of light after the use of alcohol $70^{\circ}$ and then placement of plastic bag.

The light intensity was verified by means of a radiometer of the brand ECEL RD7 previously calibrated and for each test will be carried out 5 readings, of which a final average was obtained. Between one test and another, the devices were cleaned with cotton swabs so that no other chemical could interfere with the final result of the readings obtained by the radiometer.

\section{Reading of apparatus irradiance}

13 photopolymerizers of the Schuster Emitter A FIT brand were inserted, with physical and / or chemical barriers (plastic bag, alcohol 70 , plastic bag + alcohol 70, without any barriers). The irradiance of each light curing device was evaluated through the ECEL RD7 radiometer for 5 consecutive times using the physical, chemical barriers, association of both and without any barrier. To verify the existence or not of interferences in the power of the photopolymerizers and to conclude which type of barrier would be the ideal to maintain the quality of the clinical procedures, with the resinous materials, maintaining the biosafety and avoiding the cross contamination.

\section{Results}

\section{Statistical analysis}

The exploratory analysis indicated two "outliers" (discrepant values) that were withdrawn in order for the data to satisfy the ANOVA assumptions. ANOVA was then applied, considering in the model that the same photopolymerizers were evaluated in all treatments. Multiple comparisons were performed using the Tukey test, with a significance level of $5 \%$. The analyzes were performed in program $R$

${ }^{*} \mathrm{R}$ Core Team (2017). A: A language and environment for statistical computing. R Foundation for Statistical Computing, Vienna, Austria. URL https://www.R-project.org/.

\section{Irradiance}

It can be observed in Table 1 and Figure 1 that when the irradiance was measured only with physical barrier and with both barriers (physical and chemical), the means were significantly lower than when measured with no barrier $(\mathrm{p}<0.05)$. The mean irradiance measured
Table 1. Mean (standard deviation) of the irradiance as a function of the barrier (physical and chemical)

\begin{tabular}{|c|c|}
\hline Barriers & Mean (standard deviation) \\
\hline Without any barriers & $1252,38(70,59) \mathrm{a}$ \\
\hline Chemical barrier - alcohol $70^{\circ}$ & $1199,22(68,50) \mathrm{ab}$ \\
\hline Physical barrier - plastic bag & $1186,60(65,20) \mathrm{b}$ \\
\hline Chemical and Physical barrier & $1156,00(107,28) \mathrm{b}$ \\
\hline
\end{tabular}

Means followed by distinct letters differ from each other $(\mathrm{p} \leq 0.05)$. $\mathrm{p}$ (groups) $=0.001$

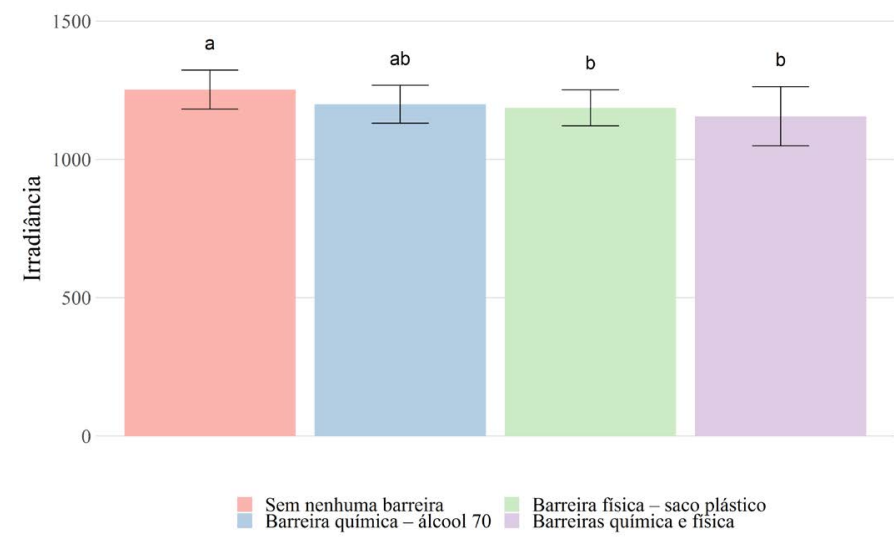

Figure 1. Mean and standard deviation of the irradiance due to the presence of barriers. Different letters indicate statistically significant differences $(\mathrm{p} \leq 0.05)$

only with the chemical barrier did not differ significantly from the other groups $(\mathrm{p}>0.05)$.

\section{Discussion}

Although the use of a protective barrier is recommended by the National Center for the Prevention of Chronic Diseases and Health Promotion (CDC) [11] for semi-critical instruments such as photopolymerizing devices, these protection means can attenuate the transmission of light and hamper the polymerization of resinous materials [12].

Several studies report the impact of the use of PVC barriers [13-15] and even the influence of alcohol $70^{\circ}$ on the physical and mechanical properties of resinous materials [16,17]. The same result was found in this study, which evidenced a higher irradiance of the light curing apparatus when no type of barrier was used. In addition, the use of chemical barrier $\left(70^{\circ}\right.$ alcohol $)$ has been quite effective in not reducing the light power of the apparatus, but, from the CDC's point of view, this protection medium should not be used individually.

This is justified because the use of barriers, mainly due to contact with the moist surfaces of the mouth (mucosa, tongue, cheek, hand) or external roughness, deviates the linear route of the appliance light [14]. In this way, wrinkles in the film also increase light drift and loss of energy. To avoid this effect, the protective films of the present study were carefully chosen, since the handling of PVC plastic is critical for some operators and the plastic bags meet the requirements of the CDC.

Physical barriers should be smooth, transparent and capable of adhering to the surface of the tip to prevent physical damage to the light output or reduce polymerization efficiency. In addition, the irradiance potential of the apparatus should be known to determine if it is high enough to ensure that the polymerization is not affected.

The results shown in Table 1 and in Figure 1 accurately translate these data, since when only alcohol was used, the irradiance remained constant in comparison to the other groups tested $\left(1199.22 \mathrm{~mW} / \mathrm{cm}^{2}\right)$. 
However, when comparing the control group (without barrier) and the group with physical barrier use and association of barriers, we can see a reduction of the same. From the clinical point of view, the reduction of values does not interfere with the polymerization, since a resinous material requires at least $400 \mathrm{~mW} / \mathrm{cm}^{2}$ so that it can be converted into polymer with a time of 40 seconds. That is, because they have high irradiance values, regardless of the type of barrier, the chance of a material being well polymerized by the tested devices remains very high, regardless of the barrier used.

The use of physical barriers is widely used because it is more practical and accessible than the use of sterilizable tips [13] that can cause irreversible damage $[14,18]$ over time. The plastic bag (physical barrier) provides effective, quick and inexpensive protection against contamination [6]. It is important to note that dental surgeons often fail to place the PVC film gently on the tip, with no wrinkles [14]. Moreover, they are not used to test light output $[13,15,16]$.

According to the studies of Baldi, et al. [18] emphasize the importance of biosafety for the protection of patients and professionals in order to avoid cross-infection; therefore, advocate a strict disinfection of the photopolymerizing devices. The study pointed out that $60 \%$ of the interviewees prefer the use of $70 \%$ alcohol as a method of electing to disinfect their devices; $33.33 \%$ of them prefer a combination of $70^{\circ}$ more plastic alcohol PVC film, and still $6.66 \%$ make use of absolute alcohol, which is not advisable [19], because according to Andrade, et al. Absolute alcohol is less effective in the antimicrobial power, when compared to the $70^{\circ}$ alcohol, because it promotes in a less efficient way the reduction of the superficial tension of the bacterial cell [20].

Therefore, because the association of barriers had the same statistical value as the use of physical barrier, the use of the chemical agent in the process guarantees the disinfection of the tips, between one service and another. Strictly speaking, $70^{\circ}$ alcohol must be stored in a suitable place and container in such a way that it does not lose its properties and is effective.

\section{Conclusion} that:

Considering the results obtained in this present study, conclude

- Physical and / or chemical barriers decrease irradiance, however, values were high, above recommended standards, and did not affect clinical procedures at the dental clinic of the Faculty of Medical Sciences and Health of Juiz de Fora - SUPREMA.

- Best barrier option is the chemical and physical association (alcohol $70^{\circ}+$ plastic bag) to better ensure biosafety and avoid crosscontamination.

\section{References}

1. Fernandes HGK, Silva R, Marinho MAS, Oliveira POS, Silva R, Ribeiro JCR, et al. (2014) Evolução da resina composta: revisão da literatura. Revista da Universidade Vale do Rio Verde 12: 401-411.

2. Marson FC, Mattos R, Sensi LG (2010) Avaliação das condições de uso dos fotopolimerizadores. Revista Dentística On-Line 9: 15-20.

3. Borges FMGS, Rodrigues CC, Freitas SAA, Costa JF, Bauer J (2011) Avaliação da intensidade de luz dos fotopolimerizadores utilizados no curso de Odontologia de Universidade Federal do Maranhão. Rev Ciênc Saúde 13: 26-30.

4. Cotrina LAD, Sousa AM, Pereira SK, Gomes OM, Gomes JC (2003) Efeito de diferentes sistemas de fotopolimerização na microdureza de uma resina composta Blach Shade. JBD Rev Iberoam Odontol Estet Dent 2: 348-357.
5. Cruz CED, Santana LRS, Bianchi EC, De Aguiar PR, Silva Junior CE, Catai RE, et al. (2008) Análise da influência dos diferentes tempos de polimerização por luz incandescente sobre a resistência ao desgaste abrasivo de resinas compostas. Materia (Rio de Janeiro) 13: 77-87.

6. Santos APD, Montandon AAB, Chávez OFM (2003) Avaliação dos fotopolimerizadores utilizados por clínicos gerais de Araraquara - SP. 20a Reunião da Sociedade Brasileira de Pesquisa Odontológica; 2003 Ago 30-Set 3; Águas de Lindoia, SP. São Paulo: Serviço de comunicação Odontológica, Faculdade de Odontologia USP - SP. Poster.

7. Briso ALF, Sundfeld RH, Costa SAC, Lima JM, Campos IT (2003) Avaliação da intensidade luminosa produzida por unidades fotoativadoras e grau de satisfação dos profissionais em empregá-las. JBC J Bras Dent Estet 2: 212-216.

8. Mori M, Shimokawa CAK, Carneiro PMA, Lobo TRS, Turbino ML (2014) Influência do método de fotoativação na dureza de uma resina composta. Clin Lab Res Dent 20: 131-136.

9. Correia IB, Teixeira HM, Nascimento ABL, Costa SX, Galindo RM, Azevedo LM, et al. (2005) Avaliação da intensidade de luz, da manutenção e do método de utilização dos fotopolimerizadores utilizados nos consultórios da cidade de Caruaru - PE. Rev Odontol UNESP 34: 113-118.

10. Pereira SK, Pascotto RC, Carneiro FP (2003) Avaliação dos aparelhos fotopolimerizadores utilizados em clínicas odontológicas. J Bras Dent Estet 2: 29-35.

11. National Center for Chronic Disease Prevention and Health Promotion. Guidelines for Infection Control in Dental Health-Care Settings. [Acessed 2018 Out 30] Available from:http://www.cdc.gov/OralHealth/infectioncontrol/guidelines/index.htm .

12. Coutinho M, Trevizam NC, Takayassu RN, Leme AA, Soares GP (2013) Distance and protective barrier effects on the composite resin degree of conversion. Contemporary Clinical Dentistry 4: 152-155

13. Warren DP, Rice HC, Powers JM (2000) Intensity of curing lights affected by barriers. $J$ Dent Hyg 74: 20-23. [Crossref]

14. Rueggeberg FA, Caughman WF (1998) Factors affecting light transmission of singleuse, plastic light-curing tips. Oper Dent 23: 179-184. [Crossref]

15. McAndrew R, Lynch CD, Pavli M, Bannon A, Milward P (2011) The effect of disposable infection control barriers and physical damage on the power output of light curing units and light curing tips. Br Dent J210: E12. [Crossref]

16. Chong SL, Lam YK, Lee FK, Ramalingam L, Yeo AC, et al. (1998) Effect of various infection-control methods for light-cure units on the cure of composite resins. Oper Dent 23: 150-154. [Crossref]

17. Pollington S, Kahakachchi N, van Noort R (2009) The influence of plastic light cure sheaths on the hardness of resin composite. Oper Dent 34: 741-745. [Crossref]

18. Rode KM, Kawano Y, Turbino ML (2007) Evaluation of curing light distance on resin composite microhardness and polymerization. Oper Dent 32: 571-578.

19. Baldi RL, Teider LD, Leite TM, Martins R, Delgado LAC, Pereira SKP (2005) Intensidade de luz de aparelhos fotopolimerizadores utilizados no curso de odontologia da universidade estadual de Ponta Grossa. Publ UEPG Ci Biol Saúde 11: 39-46.

20. Andrade D, Santos LS, Oliveira BA, Beraldo CC (2002) Álcoois: a produção do conhecimento com ênfase na sua atividade microbiana. Medicina (Ribeirão Preto) 35: 7-1.

Copyright: (C2018 de Azevedo Miranda D. This is an open-access article distributed under the terms of the Creative Commons Attribution License, which permits unrestricted use, distribution, and reproduction in any medium, provided the original author and source are credited. 